\title{
PRELIMINARY ASSESSMENT OF COI AND ITS1 SEQUENCE VARIATION IN FULLER'S ROSE WEEVIL
}

\author{
C.V. MANDER ${ }^{1}$, C.B. PHILLIPS ${ }^{2}$, T.R. GLARE ${ }^{2}$ and R.B. CHAPMAN ${ }^{1}$ \\ ${ }^{1}$ Ecology and Entomology Group, PO Box 84, Lincoln University \\ ${ }^{2}$ Biocontrol and Biosecurity Group, AgResearch, PO Box 60, Lincoln
}

Correspondingauthor: manderc@lincoln.ac.nz

\begin{abstract}
Fuller's rose weevil (FRW), Naupactus cervinus, has recently become a pest of kiwifruit in New Zealand because export fruit infested with FRW eggs do not meet Japanese quarantine standards. Studies of FRW population genetics could be useful for: (i) deducing the number and geographic sources of FRW introductions to New Zealand, (ii) matching New Zealand FRW populations with appropriate strains of biological control agents and (iii) differentiating FRW from other closely related species which may be difficult to separate morphologically (especially as larvae). This paper describes preliminary results from sequencing of two gene regions, the ITS1 (internal transcribed spacer) region and the COI (cytochrome oxidase one) gene. These sequences were used to compare FRW from New Zealand, Australia, Hawaii and Chile. The results showed that the COI region would be more useful than ITS1 for future studies of FRW population genetics.
\end{abstract}

Keywords: Naupactus cervinus, Asynonychus, Pantomorus, ITS1, COI.

\section{INTRODUCTION}

Naupactus cervinus Crotch (Coleoptera: Curculionidae), or Fuller's rose weevil (FRW), is synonymous with Asynonychus cervinus Crotch, A. godmanni Crotch and Pantomorus cervinus (Boheman) (Lanteri 1993; Alonso-Zarazaga \& Lyal 1999). The natural distribution of FRW includes Argentina, Brazil, Paraguay and Uruguay, and it is considered to have been introduced by humans to Chile (Lanteri \& Normark 1995). It has also been introduced to numerous other countries with warm, temperate climates (Chadwick 1965). The spread of this flightless weevil has probably been facilitated by its parthenogenetic reproduction (Lanteri 1993; Lanteri \& Normark 1995) and broad host plant range (May 1979). It is a pest of kiwifruit in New Zealand because export fruit infested with FRW eggs do not meet Japanese quarantine standards, and it is a pest of citrus in California, Florida and Australia (Madge et al. 1992).

The cytochrome oxidase one gene (COI) is located in the mitochondrial DNA and is often an informative gene for molecular systematics at lower taxonomic levels (Howland \& Hewitt 1995). The internal transcribed spacer (ITS1) is a variable region flanked by the $18 \mathrm{~S}$ and 5.8S rDNA genes, which generally provides sufficient nucleotide variation for subspecies separation in insects (Schlotterer et al. 1994; Richards et al. 1997).

The aim of this study was to assess the utility of nucleotide sequences from the COI and ITS1 gene regions for deducing the number and geographic sources of FRW introductions to New Zealand, matching New Zealand FRW populations with appropriate strains of biological control agents (e.g. Ferrari et al. 2001; Decaestecker et al. 2003) and differentiating FRW from other closely related species which may be difficult to separate morphologically (especially as larvae).

\section{MATERIALS AND METHODS}

Single specimens of FRW larvae or adults were obtained from six sites in four countries (Table 1). 
TABLE 1: Specimens used in this study and details of their collection.

\begin{tabular}{lllll}
\hline Specimen name & Region/Country & Location & Collector & Date \\
\hline FRW 1366 & Bay of Plenty, NZ & Matapihi & R. Townsend & $21 / 10 / 02$ \\
FRW 4761 & Auckland, NZ & Awhitu & A. Logan & $03 / 03 / 02$ \\
FRW 6449 & Victoria, Australia & Tatura & D. Wilson & $22 / 04 / 03$ \\
FRW 6453 & Victoria, Australia & Vermont & C. Phillips & $22 / 04 / 03$ \\
FRW 4598 & Hawaii, USA & Oahu & C. Phillips & $13 / 01 / 02$ \\
FRW 0055 & Region VIII, Chile & Chillan & M. Cortez & $01 / 12 / 02$ \\
\hline
\end{tabular}

\section{DNA isolation}

For specimens 4761 and 4598 (Table 1), DNA was isolated from whole specimens using the methods of Vink et al. (2003). For the remaining specimens, DNA was isolated from the heads using the methods of Richards et al. (1997).

\section{PCR amplification}

The primers TW81 and HITR (Richards et al. 1997) were used to amplify the ITS1 region. The following primers were used to amplify a fragment of COI: for specimen 4761, Mtd6-aethio and Mtd9-aethio (Vink et al. 2003); for specimen 4598, Mtd6-curculio (5'...GGRGGWTTTGGAAAYTGAYTARTTCC...3') and Mtd9-curculio (5'...CCNGGDARAATTAAAATRTMWACTTC....3'); and for the remaining specimens, C1-J-1718 and C1-N-2183 (Simon et al. 1994).

Polymerase chain reactions (PCRs) were conducted in $25 \mu \mathrm{l}$ volumes containing 0.625 units Thermoprime plus DNA polymerase (ABgene), $2.5 \mu$ l Reddy mix (ABgene), $0.5 \mu \mathrm{ldNTPs}(10 \mathrm{mM}), 1.0 \mu \mathrm{l}$ each primer $(10 \mu \mathrm{M})$ and $2 \mu \mathrm{l}$ of a $1 / 10$ dilution of isolated DNA. PCRs were performed in a Perkin Elmer thermocycler with cycling of $94^{\circ} \mathrm{C}(30 \mathrm{~s}), 50^{\circ} \mathrm{C}(45 \mathrm{~s}), 72^{\circ} \mathrm{C}(1 \mathrm{~min})$, for 30 cycles. A negative, DNA-free control, was included in all runs. Amplified products were visualised on $0.8 \%$ agarose gels alongside a 100 bp molecular ladder (Gibco BRL).

\section{Sequencing of PCR products}

PCR products were amplified in $50 \mu \mathrm{l}$ reaction volumes, using 2.6 units of Expand High Fidelity PCR System (Roche), $5 \mu \mathrm{l} 10 \mathrm{X}$ buffer with $\mathrm{MgCl}_{2}$ (Roche), $1 \mu \mathrm{dNTPs}$ $(10 \mathrm{mM}), 2 \mu \mathrm{l}$ each primer $(10 \mu \mathrm{M})$ and $4 \mu \mathrm{l}$ of a $1 / 10$ dilution of isolated DNA. Amplified products were purified using a High Pure PCR Purification Kit (Roche). Sequencing was performed by the Waikato DNA Sequencing Facility (University of Waikato, Hamilton).

\section{Analysis of sequence data}

Sequences were aligned using CLUSTAL X (Thompson et al. 1997). Phylogenetic analyses were conducted using PAUP* 4.0b10 (Swofford 2002). Data were analysed as unordered characters, no characters were excluded, all characters were equally weighted and gaps were treated as missing characters. Modeltest version 3.06 (Posada \& Crandall 1998) was used to select the maximum likelihood parameters with hierarchical likelihood ratio tests. Naupactus dissimulator (Genbank accession no. AF211489) and Naupactus xanthographus (Genbank accession no. AF211491) were used as outgroup taxa for the COI analysis (Sequeira et al. 2000).

\section{RESULTS}

There was no variation within FRW amongst the 392 characters included in the ITS analysis. No sequences could be obtained for other Naupactus species to gauge ITS variation within the genus.

Six COI haplotypes occurred among the six FRW specimens sequenced. Of the 520 characters included in the analysis, six varied due to nucleotide substitutions. The FRW sequences were distinct from those of $N$. dissimulator and $N$. xanthographus (Sequeira et al. 2000). Maximum likelihood analysis resulted in one tree with a score of 1187.2348 (Fig. 1). 


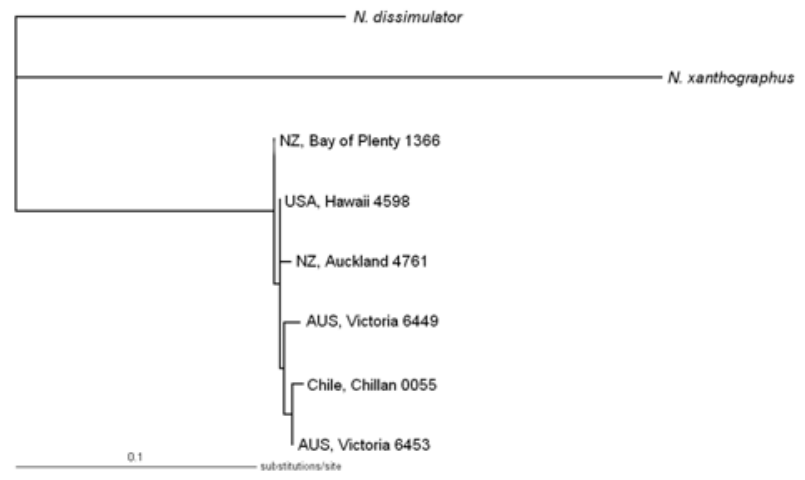

FIGURE 1: Maximum likelihood tree showing the relationships of FRW from different geographic locations based on sequencing of the internal portion of the cytochrome oxidase one (COI) gene.

\section{DISCUSSION}

The ITS1 results indicated that this gene region is unlikely to exhibit sufficient FRW intraspecific variation for population studies. Thus, these results differed from those obtained in studies of other insect taxa (e.g. Schlotterer et al. 1994; Richards et al. 1997). Ongoing efforts to sequence the ITS region from other species in the tribe Naupactini should reveal whether this region will be useful for species discrimination.

The COI results showed this gene region will be useful for discriminating between Naupactus species (Fig. 1), but it is less certain that it will be useful for studying FRW population genetics since the degree of sequence variation within FRW was small. For example, the sequences from Bay of Plenty (New Zealand) and Chile showed the most variation, but these differed at only $6 / 520(1.2 \%)$ of sites. In contrast, Normark (1996) found $1.1-7.3 \%$ COI sequence divergences within species in the Aramigus tessellatus species complex (also in the tribe Naupactini) collected in Argentina and Uruguay.

If FRW collected from its natural range exhibited variation similar to species in the A. tessellatus species complex (Normark 1996), then the low COI sequence variation observed in this study would suggest that only a few closely related parthenogenetic lineages have founded the populations in Australia, Chile, Hawaii and New Zealand. Efforts are being made to obtain specimens from within FRW's natural range so that this possibility can be tested. Also, additional specimens collected from the locations included in this study will be sequenced to enable genetic variation within these introduced populations to be gauged.

\section{ACKNOWLEDGEMENTS}

We thank Trevor Jackson and Nicky Richards (AgResearch, Lincoln) for their general support and assistance. We thank Monica Cortez (INIA), Andrea Logan (MAF, Auckland), Richard Townsend (AgResearch, Lincoln) and Derek Wilson (AgResearch, Ruakura) for providing specimens of FRW, and Rachel Cane (NZ Biosecure, Napier) and Cor Vink (Lincoln University) for assistance with PCR and primer design. We are grateful to David Teulon and Simon Bulman (Crop \& Food Research, Lincoln) for suggestions which improved an earlier version of this manuscript.

\section{REFERENCES}

Alonso-Zarazaga, M.A.; Lyal, H.C. 1999: A world catalogue of families and genera of Curculionidae (Insecta: Coleoptera) (Excepting Scolytidae and Platypodiae). Entomopraxis, Barcelona, Spain. p. 165. 
Chadwick, C.E. 1965: A review of Fuller's rose weevil (Pantomorus cervinus (Boh.)) (Col., Curculionidae). J. Entomol. Soc. Aust. (N.S.W.) 2: 10-20.

Decaestecker, E.; Vergote, A.; De Meester, L. 2003: Evidence for strong host cloneparasite species interactions in the Daphnia microparasite system. Evolution 57(4): 784-792.

Ferrari, J.; Muller, C.B.; Kraaijveld, A.R. 2001: Clonal variation and covariation in aphid resistance to parasitoids and a pathogen. Evolution 55(9): 1805-1814.

Howland, D.E.; Hewitt, G.W. 1995: Phylogeny of the Coleoptera based on mitochondrial cytochrome oxidase I sequence data. Insect Molec. Biol. 4(3): 203-215.

Lanteri, A.A. 1993: La parthenogenesis geografica y la sinonimia de Asynonychus cervinus (Boheman) Y A. godmanni Crotch (Coleoptera: Curculionidae). [Geographic parthenogenesis and synonymy of Asynonychus cervinus (Boheman) (Pantomorus cervinus) and A. godmanni Crotch (Coleoptera: Curculionidae).]. Revista de la Sociedad Entomologica Argentina 52: 100.

Lanteri, A.A.; Normark, B.B. 1995: Parthenogenesis in the tribe Naupactini (Coleoptera: Curculionidae). Annals Entomol. Soc. America 88(6): 722-731.

Madge, D.G.; Clarke, K.; Buchanan, G.A.; Wilkins, B. 1992: Seasonal abundance and distribution of Fuller's rose weevil, Asynonychus cervinus (Boheman) (Coleoptera: Curculionidae) in Sunraysia citrus groves. Plant Prot. Quarterly 7(1): 3-6.

May, B.M. 1979: Fuller's rose weevil, Asynonychus cervinus (Boheman), life cycle. DSIR Information Series 105: 1-4.

Normark, B.B. 1996: Phylogeny and evolution of parthenogenetic weevils of the Aramigus tessellates species complex (Coleoptera: Curculionidae: Naupactini): Evidence form mitochondrial DNA sequences. Evolution 50(2): 734-745.

Richards, N.K.; Glare, T.R.; Hall D.C.A. 1997: Genetic variation in grass grub, Costelytra zealandica, from several regions. Proc. 50 th N.Z. Plant Protection Conf:: 383-343.

Posada, D.; Crandall, K.A. 1998: MODELTEST: testing the model of DNA substitution. Bioinformatics 14: 817-818.

Schlotterer, C.; Hauser, M.-T.; von Haeseler, A.; Tautz, D. 1994: Comparative evolutionary analysis of rDNA ITS regions in Drosophila. Mol. Biol. Evol. 11(3): 513-522.

Sequeira, A.S.; Lanteri, A.A.; Scataglini, M.A.; Confalonieri, V.A.; Farrell, B.D. 2000: Are flightless Galapaganus weevils older than the Galápagos Islands they inhabit? Heredity 85: 20-29.

Simon, C.; Frati, F.; Beckenbach, A.; Crespi, B.; Liu, H.; Flook, P. 1994: Evolution, weighting, and phylogenetic utility of mitochondrial gene sequences and a compilation of conserved polymerase chain reaction primers. Annals Entomol. Soc. America 87(6): 651-701.

Swofford, D.L. 2002: PAUP*: Phylogenetic analysis using parsimony (*and other methods), Version 4.0b10. Sinauer Associates, Sunderland.

Thompson, J.D.; Gibson, T.J.; Plewniak, F.; Jeanmougin, F.; Higgins, D.G. 1997: he CLUSTAL X windows interface: Flexible strategies for multiple sequence alignment aided by quality analysis tools. Nucleic Acids Res. 25: 4876-4882.

Vink C.J.; Phillips C.B.; Mitchell, A.D.; Winder L.M.; Cane R.P. 2003: Genetic variation in Microctonus aethiopoides (Hymenoptera:Braconidae). Biol. Control: in press. 